\title{
角形鋼管柱・H 形はり接合部の局部耐力推定式
}

一角形鋼管柱溶接接合部の実験的研究 2-

$\begin{array}{lllll}\text { 正会員 } & \text { 田 } & \text { 㴊 } & \text { 基 } & \text { 嗣* } \\ \text { 正会員 } & \text { 金 } & \text { 谷 } & & \text { 弘** } \\ \text { 正会員 } & \text { 上 } & \text { 場 } & \text { 輝 } & \text { 康*** }\end{array}$

\section{1. 序}

外ダイアフラムにより補剛された角形鋼管柱と $\mathrm{H}$ 形 はりの溶接接合部が局部破壊する場合の耐力を解析的に 評価することは，影響する因子の数が多く，また接合部 の応力状態も複雑であるため，非常に困難である。

著者らは，接合部を単純化した模型供試体（Fig. 1) を用いて，局部破壊に関係する各因子を系統的に変化さ せた実験を行い，それらの影響を定量的に評価した耐力 推定式を回帰分析の手法を用いて誘導したのち，種々の 接合部実験結果への適用を図ることを計画した。

前報1では，1）各部材寸法を変化させた実験，2）角 形鋼管の製作方法および溶接方法による影響を調べるた めの実験，3）直交方向はりの効果を調べるための実験 の結果を報告し，接合部の局部破壊耐力と寸法因子の関 係を定性的に明らかにした。

本報告では，これらの実験結果を基にして, 耐力推定

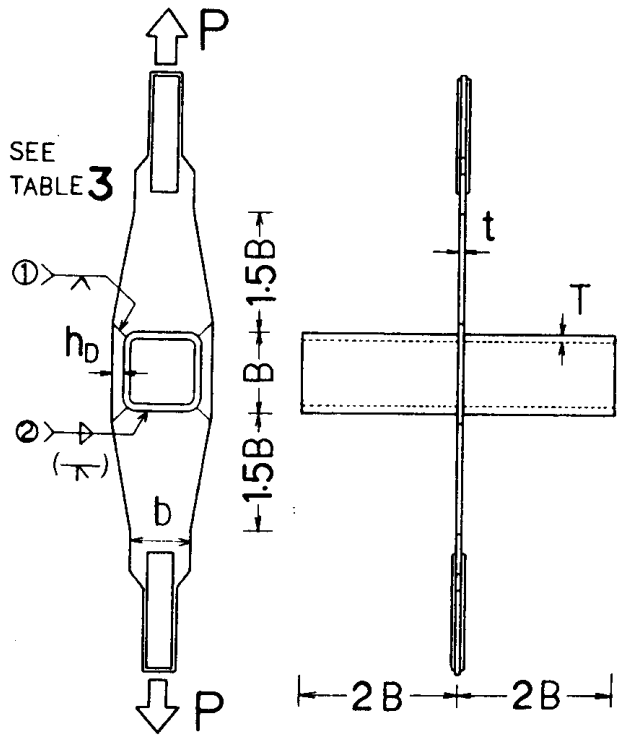

Fig. 1 Test specimen

* 神戸大学 助手・工修

** 神戸大学 教授・工博

*** 神戸大学 教務職員 工修

(昭和 59 年 3 月 5 日原稿受理日, 昭和 60 年 2 月 12 日改訂原稿受 理日, 詩論期限昭和 60 年 9 月末日)
式を誘導することを試みる。

回帰分析に用いた基本資料は，実験変数の範囲が限ら れている以外に，1）鋼種が限られている，2）鋼管の製 作方法が限られている，3）はりフランジより緩やかな テーパー部をもつダイアフラム形状に限られている，4） 対称引張荷重を受ける場合のみである，等の問題がある ため,これらの点について誘導した耐力推定式の適用範 囲を検討する。さらに，はりフランジ板の破断あるいは ダイアフラムせいが0であるため基本資料より除外した ものについても検討する。最後に，提案式が，より実際 の柱・はり接合部の状態に近い十字形供試体の実験結果 にも適用可能であることを示す。

\section{2. 実験式の誘道}

前報1で，Fig.1に示すダイアフラムで補剛された接 合部が局部破壊する場合，接合部耐力と部材寸法の間に は高い相関があり，各寸法因子が互いに他と独立とみな しうることを示した。本章では, それらの結果を基に回 䚻分析の手法を利用して耐力推定式の誘導を行う。

2-1 局部破壊耐力推定式

接合部の局部破壊耐力を支配する物理量は接合部の部 材寸法と素材の機械的性質である。ここでは，素材の機 械的性質としてダイアフラムの引張強さ $\sigma_{u s}$ 注)を選ぶ。

耐力の無次元量 $P_{\text {max }} / \sigma_{u s} \cdot B^{2}$ に関して, 無次元化さ れた寸法因子 $T / B, t / B,\left(h_{D}+T\right) / B$ が互いに独立で あることより，局部破壊耐力に関する数式モデルとして (1) 式の形を選ぶ。

$$
\frac{P_{\max }}{\sigma_{u s^{\cdot}} \cdot B^{2}}=x_{1}\left(\frac{T}{B}\right)^{x_{2}}\left(\frac{t}{B}\right)^{x_{3}}\left(\frac{h_{D}+T}{B}\right)^{x_{4}} \cdot \varepsilon
$$

ここで，ยは誤差項である。

前報で報告した実験 I の供試体のうち $h_{D} \neq 0$ で, 接 合部の局部破壊で耐力が決定した Table 1 に示す 18 体 の実験結果について, 最小二乗法により係数および指数 $x_{1} \sim x_{4}$ を決定する。

結果として, 次式の耐力推定式を得る。 


$$
\frac{P_{c \max }}{\sigma_{u s^{\cdot} \cdot B^{2}}}=4.78\left(\frac{T}{B}\right)^{0.669}\left(\frac{t}{B}\right)^{0.727}\left(\frac{h_{D}+T}{B}\right)^{0.340}
$$

ここで， $\sigma_{u f}$ としてダイアフラム素材の引張試験より 得た引張強さを使用した以外，寸法諸元はすべて公称値 によっている。

18 体の実験値と（2）式による推定値との比の変動 係数は $\mathrm{COV}=0.084$ である。

式の表現を簡便にするため，（2）式における指数 0.669 および 0.727 を $2 / 3$ に， 0.340 を $1 / 3$ にまるめ, 推定式と局部破壊した 18 体の実験値との不偏分散が最 小になるように係数を選ぶ。結果は（3）式となる。

$$
\frac{P_{c \max }}{\sigma_{u s} \cdot B^{2}}=3.85\left(\frac{T}{B}\right)^{2 / 3}\left(\frac{t}{B}\right)^{2 / 3}\left(\frac{h_{D}+T}{B}\right)^{1 / 3}
$$

実験値と（3）式による推定値との比の変動係数は $C O V=0.087$ で，(2) 式のときの値と大差はない。

\begin{tabular}{|c|c|c|c|c|c|c|c|c|c|}
\hline Specimen & $\mathrm{B} \times \mathrm{B} \times \mathrm{T}$ & $t$ & $h_{D}$ & $P_{y}$ & $P_{\max }$ & $\overline{\mathrm{P}_{\mathrm{cy}}}$ & $P_{\mathrm{cma}}$ & & \multirow{2}{*}{$\mathrm{P}_{\text {max }}$} \\
\hline TS-9A & $\sqrt{200 \times 200 \times 9}$ & 12 & 20 & 38.4 & 73.7 & 39. & & & \\
\hline TW-6B & & 9 & 40 & 34.0 & .4 & 35.7 & 1.6 & 0.95 & 0.96 \\
\hline $\mathrm{T}$ & & 9 & 30 & 29.3 & 54.4 & 27.7 & 47.7 & 1.06 & 1.14 \\
\hline & $200 \times 200 \times 6$ & & 20 & 24.8 & $39.6=$ & 24.2 & 41.7 & 1.02 & 0.95 \\
\hline & & & 20 & 21.0 & 37.6 & 22.8 & 39.3 & 0.92 & 0.96 \\
\hline & & & 20 & 14.0 & $23.0 *$ & 14.7 & 5.3 & 0.95 & 0.91 \\
\hline T & & & 40 & 34.0 & 50.5 & 29.1 & 0.2 & 1.17 & 1.01 \\
\hline $\mathrm{TH}-4$. & $200 \times 200$ & 9 & 30 & 24.0 & $37.8 *$ & 22.5 & 38.8 & 1.07 & 0.97 \\
\hline TS & $\times 4.5$ & 0 & 20 & 23.0 & 37.0 & 19.6 & 33.8 & 1.17 & 1.10 \\
\hline & & 6 & 20 & 18.0 & 36.8 & 18.4 & 31.8 & 0.98 & 1.16 \\
\hline & $200 \times 200$ & 6 & 20 & 10.0 & & 11.2 & 19.3 & 0.90 & 1.10 \\
\hline & $x^{3}, 2$ & & 20 & 8.0 & & 7.7 & 13.3 & 1.04 & \\
\hline TS- & $\times 3.2$ & 3.2 & 20 & 6.0 & 9.7 & 5.9 & 10.1 & 1.02 & 0.96 \\
\hline T15S-6 & $150 \times 150 \times 6$ & T & 15 & 21.0 & 39.4 & 21.3 & 36.7 & 0.99 & 1.07 \\
\hline TISS & & 9 & 15 & 20.0 & 32.6 & 19.0 & 32.7 & 1.05 & 1.00 \\
\hline $\mathrm{T} 15 \mathrm{~S}-4.5 \mathrm{~B}$ & 50 & 9 & 15 & 17.0 & 27.7 & 17.6 & 30.3 & 0.97 & 0.92 \\
\hline T30S-6B & $300 \times 6$ & 9 & 30 & 33.0 & $49.1 \%$ & 32.9 & 56.7 & 1.00 & 0.87 \\
\hline $\mathrm{T} 30 \mathrm{~S}-4.5 \mathrm{~B}$ & 300 & 9 & 30 & 25.0 & $41.2 \%$ & 26.8 & 46.1 & 0.93 & 0.89 \\
\hline T0-9 & & 9 & & 240 & 50 & 22.8 & 39.4 & 1.05 & 1.27 \\
\hline & & & & 5 & 24 & $\mid 14.6$ & 25.2 & 1.06 & 0.96 \\
\hline $\mathrm{T} 0-4.5 \mathrm{~B}$ & & & 0 & 11.0 & 17.9 & 11.0 & 18.9 & 1.00 & 0.95 \\
\hline
\end{tabular}

Table 1 Comparison between Test and Predicted Results

* Poor Welding

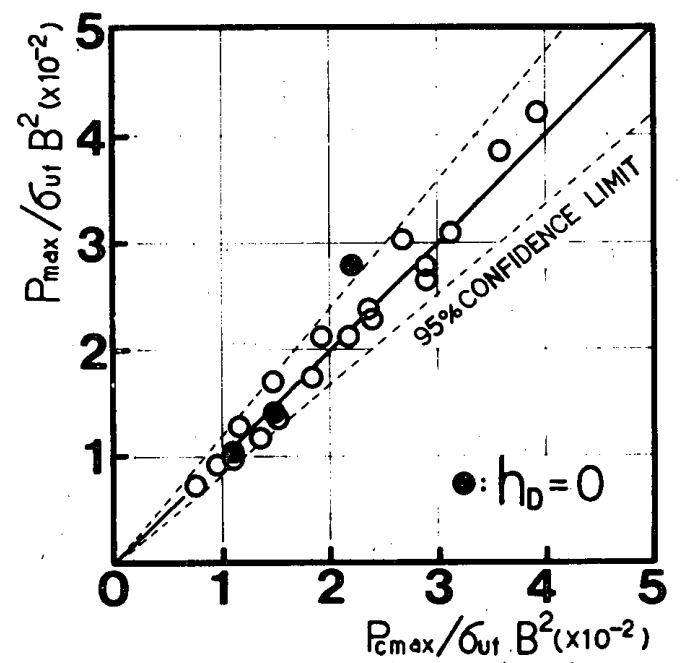

Fig. 2 Comparison between $P_{\max }$ and $P_{c \max }$
さらに，パラメータの組み替えを行い，最終的に次式 の局部破壊耐力推定式を得る。

$$
\frac{P_{c \max }}{\sigma_{u f^{\prime}} \cdot B^{2}}=3.85\left(\frac{T}{B}\right)^{2 / 3}\left(\frac{t}{h_{D}+T}\right)^{2 / 3}\left(\frac{h_{D}+T}{B}\right)
$$

ここで, $T / B, t /\left(h_{D}+T\right)$, および $\left(h_{D}+T\right) / B$ はそ れぞれ柱の幅厚比，ダイアフラム部の幅厚比，ダイアフ ラムせいと柱幅の比である。

実験值と（4）式による推定值の比較を Table 1 およ びFig. 2 に示す。図の縦軸は実験值で，（4）式の左辺 と同様 $\sigma_{u s} \cdot B^{2}$ で無次元化している。図中の破線は誤差 が対数正規分布するものとして求めた ${ }^{2), 37} 95 \%$ 信頼帯 を示している。信頼帯の幅は $P_{\text {max }} / P_{c \text { max }}=0.84 \sim 1.19$ であり，推定式は実験値を精度良く評価し得ている。

\section{2-2 局部降伏耐力推定式}

降伏耐力（荷重一全体変形関係における接線剛性が初 期剛性の $1 / 3$ になる時の荷重）についても，最大耐力と 同様に無次元化耐力 $P_{y} / \sigma_{u r^{*}} B^{2}$ に対して各寸法因子を 独立変数として扱うことができ，最大耐力の場合と同様 の方法で耐力推定式を誘導することができる。しかし， 最大耐力と降伏耐力では，耐力に与える各寸法因子の効 果が異なっているため, その方法で得られる耐力推定式 における各寸法因子の項の指数は最大耐力の場合とは異 なる。ここでは，耐力式としての簡便さを重視し次のよ うに考える。すなわち，（4）式誘導の基になった 18 体 について，降伏耐力と最大耐力の実験値の比を求めると 0.47 〜 0.67 であり, その平均值は 0.58 , 変動係数は 0.098 で比較的挾い範囲にある。このバラツキの程度は $P_{\max } / P_{c \max }$ の場合と同程度である。したがって, 降伏 耐力推定式としては $(4)$ 式に $P_{y} / P_{\max }$ の平均值を乗 じた次式とする。

$$
P_{c y}=0.58 P_{c \max }
$$

対象とした 18 体の供試体の実験値と（5）式による

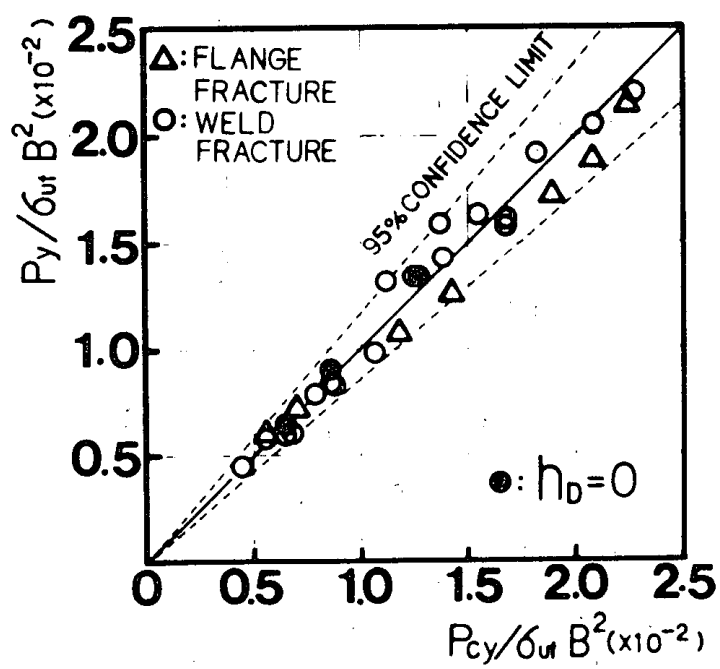

Fig. 3 Comparison between $P_{y}$ and $P_{c y}$ 
推定值を Table 1 に示す。実験値と推定值の比の変動係 数は $C O V=0.076$ である。

Fig. 3 に無次元化した実験值と推定値の関係を○印で 示している。Fig. 3 の破線は最大耐力の場合と同様に $95 \%$ 信頼帯を示している。その幅は $P_{y} / P_{c y}=0.86 \sim 1$. 16 であり，最大耐力の場合より若干挾くなっており，

（5）式により実験值を精度良く推定し得ている。

\section{3. 適用範囲の検討}

前章において，はりフランジより緩やかなテーパー部 をもつダイアフラムにより補剛され，フランジ板より対 称引張荷重をうける接合部が，局部破壊する場合につい て，(4) 式および（5）式を導いた。

そこで対象とした接合部の各部寸法の範囲は, $B / T$ $=22 \sim 67, h_{D} / B=0.1 \sim 0.2, t / T=0.75 \sim 2.0$ で，使用 材の鋼種はSTKR 41 および SS 41 で（ $\sigma_{u f}=3.34 \sim 5.40$ $\left.\mathrm{t} / \mathrm{cm}^{2}\right)$ ，溶接にはJIS D 4301 に相当する溶接棒が使用 されている。

本章では，提案した耐力推定式の適用範囲を調べるた め上記の諸条件を満足しない場合についての実験結果と 推定式の比較検討を行う。

\section{3-1 フランジ板破断の場合}

前報で述べたようにフランジ板の破断で最大耐力に達 した場合でも接合部の降伏は局部降伏により決定されて おり, 継手効率 $P_{y} / \sigma_{y f} \cdot A_{f}\left(\sigma_{y f} \cdot A_{f}\right.$ : フランジ板の降伏 酎力）は 1.0 より小さい。これらの供試体の中にはダイ アフラム厚と鋼管厚の比 $t / T$ が推定式誘導の基になっ た供試体の下限値 0.75 より小さいものも含まれている。

降伏耐力の実験値と（5）式による推定值を Table 2 に示す。Fig. 3 に両者の関係を $\Delta$ 印で示す。すべての実 験值は $95 \%$ 信頼帯内に入っており，最終的にフランジ 板の破断で耐力が決まった場合でも，接合部が局部降伏 している限り，（5）式により降伏耐力を推定すること ができる。

3-2 $h_{D}=0$ の場合
柱よりの突出部が無く，鋼管外径と等幅になるような テーパーのついたフランジ板が直接鋼管に溶接された $\left(h_{D}=0\right)$ 接合部の実験值と推定值を Table 1 に示す。 ここで，推定值は（4）式および（5）式において $h_{D}$ $=0$ とすることにより得られる。Fig. 2 および Fig. 3 に

印で実験值と推定值の関係を示す。最大耐力および降 伏耐力とも推定式は実験結果を精度良く推定しており両 式は $h_{D}=0$ の場合でも有効である。

\section{3-3＼cjkstart鋼種の違いによる影響}

本節では，（）鋼管およびダイアフラムともに高張力 鋼を使用した場合， ii ）鋼管あるいはダイアフラムのよ゙ ちらか一方のみが高張力鋼である場合について，実験結 果と推定值を比較検討し，推定式の適用範囲を調べると ともに，推定式中に使用材の強度特性を表す指標として ダイアフラム材の引張強さ $\sigma_{u f}$ を使用したことの妥当性 についても検討する。

供試体の寸法および使用材の機械的性質を Table 3 に示す。SM 58 Q および管厚 $6 \mathrm{~mm}$ の SM $50 \mathrm{~A}$ 材を用 いた角形鋼管は冷間プレス成形されたみぞ形断面材を 2 本溶接して製作されている(以下プレス成形鋼管)。そ の他のものはすべて冷間ロール成形による角形鋼管（以 下ロール成形鋼管）である。各供試体ともフランジ板と ダイアフラムは同一鋼板より製作されている。溶接はす ベてアーク手溶接である。使用した溶接棒は $41 \mathrm{~kg} / \mathrm{mm}^{2}$, $50 \mathrm{~kg} / \mathrm{mm}^{2}$ および $58 \mathrm{~kg} / \mathrm{mm}^{2}$ 級の鋼材に対してそれぞ れD 4301 (イルミナイト系)，D 5016 (低水素系) およ

Table 2 Comparison between Test and Predicted Results for Specimens Fractured in Flange

\begin{tabular}{l|r|rr|r|r|r|r}
\hline \multirow{2}{*}{ Specimen } & $\mathrm{B} \times \mathrm{B} \times \mathrm{T}$ & $\mathrm{t}$ & $\mathrm{h}_{\mathrm{D}}$ & $\mathrm{P}_{\mathrm{y}}$ & $\mathrm{P}_{\mathrm{Cy}}$ & $\frac{\mathrm{P}_{\mathrm{y}}}{\mathrm{P}_{\mathrm{Cy}}}$ & $\frac{\mathrm{P}_{\mathrm{y}}}{\sigma_{\mathrm{yf}} \cdot \mathrm{Af}}$ \\
\hline TW-9B & & 9 & 40 & 46.0 & 47.8 & 0.96 & 0.96 \\
$\mathrm{TH}-9 \mathrm{~B}$ & & 9 & 30 & 34.0 & 37.2 & 0.91 & 0.86 \\
$\mathrm{TS}-9 \mathrm{~B}$ & $200 \times 200 \times 9$ & 9 & 20 & 29.0 & 31.5 & 0.92 & 0.85 \\
$\mathrm{TS}-9 \mathrm{C}$ & & 6 & 20 & 21.0 & 24.0 & 0.88 & 0.86 \\
$\mathrm{TS}-9 \mathrm{D}$ & & 4.5 & 20 & 15.0 & 16.5 & 0.91 & 0.88 \\
TS-4.5D & $200 \times 200$ & 4.5 & 20 & 10.0 & 9.8 & 1.02 & 0.59 \\
TS-4.5E & $\times 4.5$ & 3.2 & 20 & 8.0 & 7.5 & 1.07 & 0.73 \\
\hline
\end{tabular}

Table 3 Details of Test Specimens and Mechanical Properties

\begin{tabular}{|c|c|c|c|c|c|c|c|c|c|c|c|c|c|}
\hline \multirow[b]{2}{*}{ Specimen } & \multirow{2}{*}{\multicolumn{2}{|c|}{$\mathrm{B} \times \mathrm{B} \times \mathrm{T}$}} & \multirow[b]{2}{*}{$\mathrm{b}$} & \multirow[b]{2}{*}{$\mathrm{t}$} & \multirow[b]{2}{*}{$\mathrm{h}_{\mathrm{D}}$} & \multirow{2}{*}{\multicolumn{2}{|c|}{\begin{tabular}{|c|} 
Weld \\
details \\
(1) (2)
\end{tabular}}} & \multicolumn{3}{|c|}{ RHS } & \multicolumn{3}{|c|}{ Diaphragm(Flange) } \\
\hline & & & & & & & & Grade & \multicolumn{2}{|c|}{${ }^{\sigma} \mathrm{yc} / \mathrm{cm}^{2} \mathrm{uc}$} & Grade & \multicolumn{2}{|c|}{$\sigma_{\mathrm{y}} \mathrm{E}_{/ \mathrm{cm}}{ }^{\sigma} \mathrm{uf}$} \\
\hline TS $-6 \mathrm{Bt}$ & \multirow{4}{*}{200} & \multirow{4}{*}{2006} & \multirow{4}{*}{150} & \multirow{4}{*}{9} & \multirow{4}{*}{20} & $\mathrm{v}$ & $\bar{F}$ & SS $41 \%$ & 3.73 & 4.94 & $5 S 41$ & 2.94 & 4.38 \\
\hline TS $-6_{H^{B}}$ & & & & & & V & F & SM58Q** & 5.37 & 6.03 & SS 41 & 2.59 & 4.43 \\
\hline TS $\quad-6_{H} B_{H}$ & & & & & & V & F & SM $58 Q * * 1$ & 5.37 & 6.03 & SM58Q & 6.28 & 6.93 \\
\hline TS $\quad-6 B_{H}$ & & & & & & V & F & SS $41 \%$ & 3.19 & 4.18 & SM58Q & 6.28 & 6.93 \\
\hline \multirow{6}{*}{$\begin{array}{l}\text { T25S-6B } \\
\text { T25S-6 }{ }_{H}^{B} \\
\text { T25S-6 }{ }_{H}^{B} B_{H} \\
\text { T25S-6 }{ }^{B} H \\
\text { T25H-6 }{ }_{H} B_{H} \\
\text { T25S-6 }{ }_{H} C_{H}\end{array}$} & \multirow{6}{*}{250} & \multirow{6}{*}{2506} & \multirow{6}{*}{188} & \multirow{4}{*}{9} & \multirow{4}{*}{25} & V & $\bar{F}$ & $\operatorname{SS} 41 *$ & 3.69 & 4.76 & 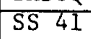 & 3.13 & 4.80 \\
\hline & & & & & & V & $\mathrm{F}$ & SM50A*** & 3.50 & 5.27 & SS 41 & 3.13 & 4.80 \\
\hline & & & & & & V & $\mathrm{F}$ & SM50A** & 3.50 & 5.27 & SM50A & 3.67 & 5.39 \\
\hline & & & & & & V & $\mathrm{F}$ & SS $41 *$ & 3.69 & 4.76 & SM50A & 3.67 & 5.39 \\
\hline & & & & 9 & 37.5 & v & $\mathrm{F}$ & SM $50 A^{*} * *$ & 3.50 & 5.27 & SM50A & 3.62 & 5.36 \\
\hline & & & & 6 & 25 & $\mathrm{~V}$ & $\mathrm{~F}$ & SM50A** & 3.50 & 5.27 & SM50A & 3.50 & 5.27 \\
\hline \multirow{3}{*}{$\begin{array}{l}\text { T25S-9 } \mathrm{H}^{\mathrm{A}} \\
\text { T25S-9 } \mathrm{H}_{\mathrm{H}}^{\mathrm{A}} \\
\text { T25S-9 } \mathrm{AH}^{2}\end{array}$} & \multirow{3}{*}{250} & \multirow{3}{*}{2509} & \multirow{3}{*}{188} & \multirow{3}{*}{12} & \multirow{3}{*}{25} & $\mathrm{~V}$ & $\tau$ & SM50* & 4.90 & 5.58 & SS 41 & 3.09 & 4.73 \\
\hline & & & & & & $\mathrm{v}$ & v & SM50* & 4.90 & 5.58 & SM50A & 3.76 & 5.67 \\
\hline & & & & & & $\mathrm{V}$ & i & SS $41 *$ & 3.83 & 4.57 & SM50A & 3.76 & 5.67 \\
\hline \multicolumn{14}{|c|}{ * : RHS formed by cold rolling } \\
\hline$\dot{t}:$ A spe & 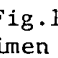 & & $; \mathrm{V}$ & & & & 81 & bevel & groc & , & $\mathrm{F}$; & let & eld \\
\hline
\end{tabular}


び D 5816 （低水素系）相当品であり，異種の鋼材間の 溶接はグレードの高い方にあわせて溶接棒を選んだ。

実験結果および推定値を Table 4 に示す。同表の破 壊モードの欄中*を付したものは，柱コーナ一部のすみ 肉寸法が不足しており，またダイアフラムビうしの溶接 部の溶け込みも不十分であったため早期にきれつが生じ た供試体である。そこで，その後に実験を行った**を 付した 2 体については，柱のコーナ一部およびダイアフ ラム部の溶接を補修した。その結果,これら 2 体は柱コー ナ一部の柱側溶接止端部あるいはダイアフラム母材のき れつで最大耐力に達した。

Fig. 4 Fig. 6 に各シリーズの荷重一局部変形関係を 示す。

\section{3-3-1 高張力鋼よ゙うしの接合部}

供試体は 5 体であり，そのうちの 2 体，TS-6 ${ }_{H} B_{H}$ および $T 25 S-6_{H} B_{H}$ については同じ寸法諸元をもち, 柱, ダイアフラムとも普通鋼の場合の実験結果と比較す る。

Fig. 4 および.Fig. 5 の荷重一局部変形関係において, 降伏後の同一変形時における高張力鋼どうしと普通鋼ど うしの供試体の荷重の比は, TS-6 B シリーズで大略 1.5, T $25 \mathrm{~S}-6 \mathrm{~B}$ シリーズで 1.2 1.3 である。この值 はダイアフラム材の引張強さの比 1.58 ( TS-6 B シ リーズ), 1.12 (T $25 \mathrm{~S}-6$ B.シリーズ) にほぼ対応し
ている。このことは, 高張力鋼を使用した場合も接“合部 耐力は $\sigma_{u s}$ に支配されると考えて良いことを示してい る。

Fig. 7 およびFig. 8 に最大耐力および降伏耐力の実 験値と推定値の関係をの印で示す。すみ肉寸法が不足し ていたため早期のきれつが生じた $T 25 S-6_{H} B_{H}$ の最大 耐力は推定值より低く，溶接部を補修した $T 25 H-6_{H}$ $B_{H}$ および $T 25 S-6_{H} C_{H}$ の最大耐力は推定値より $30 \%$ 近く高目になっている。しかし，それらの供試体の降伏 耐力および他の 2 体の降伏耐力と最大耐力は $(4)$ 式, ( 5 ）式の $95 \%$ 信頼帯の幅の中に入っており, 柱およ びダイアフラムとも高張力鋼を使用した場合でも耐力推 定式は有効であることが分かる。

\section{3-3-2 異種の鋼材を用いた接合部}

1）柱は普通鋼でダイアフラムが高張力鋼の場合：

対象となる供試体は $T S-6 B_{H}, T 25 S-6 B_{H}$ および $T 25 S-9 A_{H}$ の 3 体である。柱およびダイアフラムとも に高張力鋼で製作されている供試体とこれらの供試体と の強度の差は柱の鋼種の違いによる。Table 5 には降伏 時およびFig.4 Fig. 6 の $P-\delta_{L}$ 関係において降伏後 の同一変形時における両者の荷重の比を示している。同 表には柱の降伏点の比も示しているが, 柱の降伏点の差 ほど供試体の耐力差はなく, 接合部耐力は柱素材の降伏 点に支配されていないことが分かる。

Table 4 Summary of Test and Predicted Results

\begin{tabular}{|c|c|c|c|c|c|c|c|c|c|c|c|c|c|c|c|}
\hline \multirow{2}{*}{\multicolumn{2}{|c|}{ Specimen }} & $y$ & $P_{\max }$ & $y$ & $\delta_{\max }$ & $\delta_{\operatorname{Lmax}}$ & \multirow{2}{*}{$\frac{P_{y}}{P_{\max }}$} & \multirow{2}{*}{$\frac{P_{y}}{\sigma_{y f} f \cdot A f}$} & \multirow{2}{*}{$\frac{P_{\max }}{\sigma_{\mathrm{uf}} \mathrm{Af}}$} & \multirow{2}{*}{$\frac{\delta_{\mathrm{L} \max }}{2 \mathrm{~T}}$} & $P_{c y}$ & $\mathrm{P}_{\text {cmax }}$ & \multirow{2}{*}{$\frac{P_{y}}{P_{c y}}$} & \multirow{2}{*}{$\frac{P_{\max }}{P_{\text {cmax }}}$} & \multirow{2}{*}{$\begin{array}{l}\text { Failure } \\
\text { Mode }\end{array}$} \\
\hline & & \multicolumn{2}{|c|}{$\operatorname{ton} \mathrm{f}$} & & $\mathrm{min}$ & & & & & & \multicolumn{2}{|c|}{ tonf } & & & \\
\hline $\begin{array}{l}\text { TS } \\
\text { TS }\end{array}$ & $6 \mathrm{HB}$ & $\begin{array}{l}4.8 \\
0.0\end{array}$ & $\begin{array}{l}39.6 \\
62.9\end{array}$ & 0.48 & $\begin{array}{r}7.6 \\
22.7\end{array}$ & $\begin{array}{r}5.6 \\
22.8\end{array}$ & $\begin{array}{l}0.63 \\
0.48\end{array}$ & $\begin{array}{l}0.62 \\
0.76\end{array}$ & $\begin{array}{l}0.67 \\
0.93\end{array}$ & $\begin{array}{l}0.47 \\
1.90\end{array}$ & $\begin{array}{l}24.2 \\
26.6\end{array}$ & $\begin{array}{l}41.7 \\
45.9\end{array}$ & $\begin{array}{l}1.03 \\
1.13\end{array}$ & $\begin{array}{l}0.95 \\
1.37\end{array}$ & $\begin{array}{l}W^{*} \\
C, W\end{array}$ \\
\hline TS & $-6 H B_{H}$ & 38.0 & 59.7 & 0.90 & 8.1 & 9.0 & & 0.45 & 0.64 & 0.75 & 38.3 & 66.0 & 0.99 & 0.90 & W \\
\hline TS & $-6 \mathrm{BH}_{\mathrm{H}}$ & 36.0 & 48.5 & 1.04 & 4.1 & 4.4 & 0.74 & 0.42 & 0.52 & 0.37 & 38.3 & 66.0 & 0.94 & 0.73 & $W^{*}$ \\
\hline T25 & $3-6 B$ & 31.0 & 47.7 & 2.06 & 9.9 & 10.5 & 0.65 & 0.58 & 0.58 & 0.88 & 30.3 & 52.3 & 1.02 & 0.91 & $\hat{\mathrm{W}}$ \\
\hline $\mathrm{T} 2$ & $6 \mathrm{H}^{B}$ & 27.0 & 44.5 & 0.68 & 5.8 & 7.5 & 0.61 & 0.50 & 54 & 3 & 30.3 & 52.3 & 39 & & $C *$ \\
\hline $\mathrm{T} 25$ & $6 \mathrm{HBH}$ & 39.0 & 50 & & 5.4 & 5.4 & & & & & 34.0 & 58.7 & 1.15 & 0.86 & $C *$ \\
\hline $\mathrm{T} 25$ & $-6 \mathrm{BH}$ & 38.0 & 58.0 & 2.06 & 11.3 & 12.0 & 66 & 0.61 & 3 & 00 & 34.0 & 58.7 & 1.12 & & $\mathrm{C}$ \\
\hline $\mathrm{T} 25$ & $6 \mathrm{HBH}$ & 42.0 & 83.9 & 1.04 & 21.4 & 20.5 & 0.50 & 0.68 & 0.92 & 1.71 & 37.9 & 65.3 & 1.11 & 1.28 & $C^{* *}$ \\
\hline T25 & $6 \mathrm{HCH}$ & 28.0 & 55.5 & 1.43 & 25.8 & 8.0 & 0.51 & 0.70 & 0.92 & 0.67 & 25.4 & 43.8 & 1.10 & 1.27 & $W *$ \\
\hline $\mathrm{T} 25$ & $\mathrm{HA}$ & 54.0 & 96.9 & 1.88 & 22.2 & 18.3 & 0.56 & 0.77 & 0.90 & 1.02 & 48.9 & 84.3 & 1.11 & 1.15 & $\mathrm{C}$ \\
\hline $\mathrm{T} 2$ & $\mathrm{HAH}$ & 64.0 & 100.7 & 1.92 & 11.0 & 13.9 & 64 & 0.75 & 0.78 & 0.77 & 58.6 & & & 1.00 & C \\
\hline $\mathrm{T} 25$ & $3-9$ AH & 56.0 & 96.4 & 1.24 & 14.2 & 19.3 & 0.58 & 0.65 & 0.75 & 1.07 & 58.6 & 1.01 .0 & 0.96 & 0.95 & $\mathrm{C}$ \\
\hline
\end{tabular}

$C$ : Crack in weld at column corner

* : Poor welding.

W : Crack in butt weld

$* *$ : Repair welding

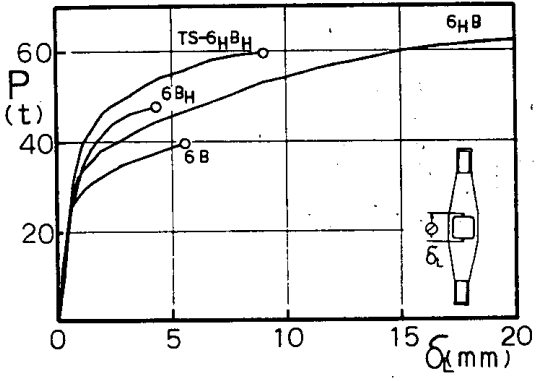

Fig. $4 P-\delta_{L}$ Curves ( $T S-6 B$ series)

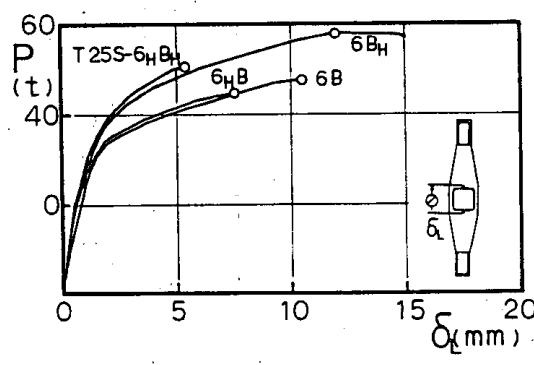

Fig. $5 P-\delta_{L}$ Curves $(T 25-6 B$ series)

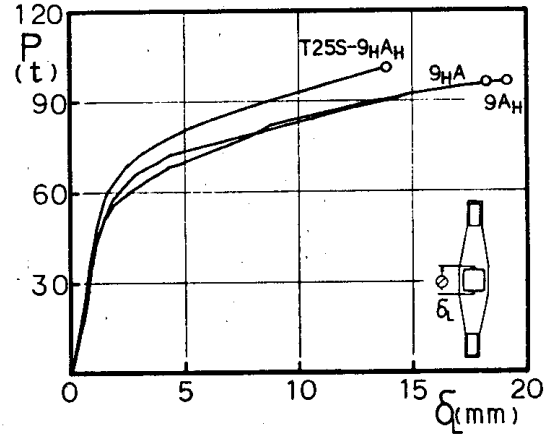

Fig. 6. $P-\delta_{L}$ Curves $(T 25-6 B$ series $)$ 


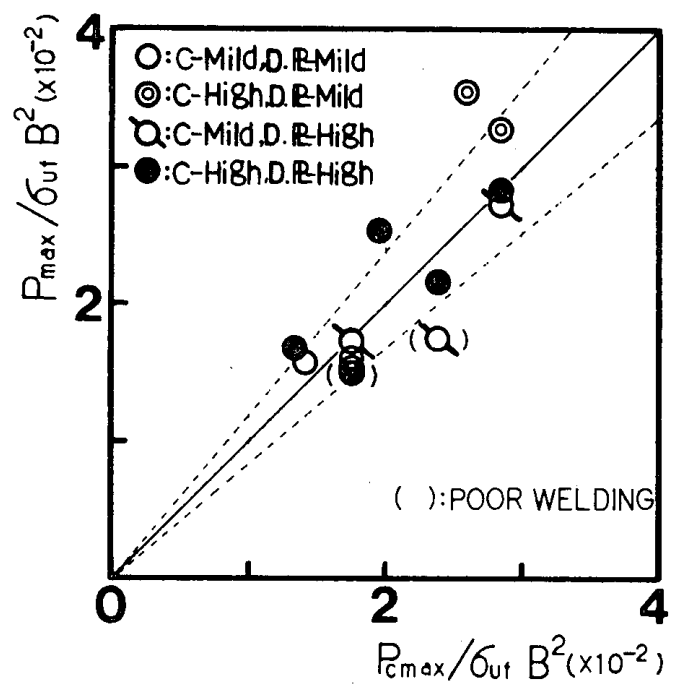

Fig. 7 Comparison between Pmax and Pcmax

Fig. 7 およびFig. 8 に実験値と推定値の関係を Q印 で示す。溶接部の溶け込み不足のためその部分に早期に きれつが入った $T S-6 B_{H}$ の最大耐力以外，実駼值はす べて $95 \%$ 信頼帯内に入っており，使用材の材料特性を 表す指標としてダイアフラム材の引張強さ $\sigma_{u s}$ を用いた （4）式および（5）式の耐力推定式によりこの種の異 種鋼材接合部の耐力評価は可能である。

2）ダイアフラムは普通鋼で柱が高張力鋼の場合： 対象となる供試体は $T S-6_{H} B, T 25 S-6_{H} B$ および $T 25 S-9_{H} A$ の 3 体である。

Table 6 に，柱およびダイアフラムとも高張力鋼の場 合の供試体とこれらの供試体との降伏時および $P-\delta_{L}$ 関係における降伏後の同一変形時の荷重の比を示す。 同表にはダイアフラム材の強度の比も示している。高張 力鋼として SM 50 材を用いた T $25 \mathrm{~S}$ シリーズではダ イアフラム材の強度差は比較的小さく, また両者の荷重 の比もその程度である。一方, 高張力鋼として SM 58 Q 材を使用した TS-6 B シリーズでは，ダイアフラム 材の強度差ほど供試体の耐力差はなく，ダイアフラム材 の強度が必ずしも接合部耐力を支配していない。

Fig. 7 おびFig. 8 に実験値と推定值の関係を@印 で示している。推定式は耐力を過少評価する傾向にあり， 最大耐力においてそれが顕著である。

対象とした供試体はいずれも溶接部に生じたきれつで 耐力が決定した。ここでの供試体の溶接には高張力鋼用 の溶接棒が使用されている。伴, 藤原 ${ }^{4)}$ は異種の鋼材の

Table 5

\begin{tabular}{c|c|c|c|c|c}
\hline & $P_{y}$ & $P-\delta_{L}$ & $P_{\max }$ & $\sigma_{y c}$ & $\sigma_{u c}$ \\
\hline$\frac{T S-6 \mathrm{H}_{\mathrm{H}}}{\mathrm{TS}-6 \mathrm{BH}_{\mathrm{H}}}$ & 1.06 & 1.10 & $<1.23$ & 1.68 & 1.44 \\
\hline$\frac{\mathrm{T} 25 \mathrm{~S}-5 \mathrm{H} \mathrm{BH}_{\mathrm{H}}}{\mathrm{T} 25 \mathrm{~S}-6 \mathrm{BH}}$ & 1.03 & 1.04 & $>0.87$ & 0.95 & 1.11 \\
\hline$\frac{\mathrm{T} 25 \mathrm{~S}-9 \mathrm{HAH}}{\mathrm{T} 25 \mathrm{~S}-9 \mathrm{AH}}$ & 1.14 & 1.10 & 1.04 & 1.28 & 1.22 \\
\hline
\end{tabular}

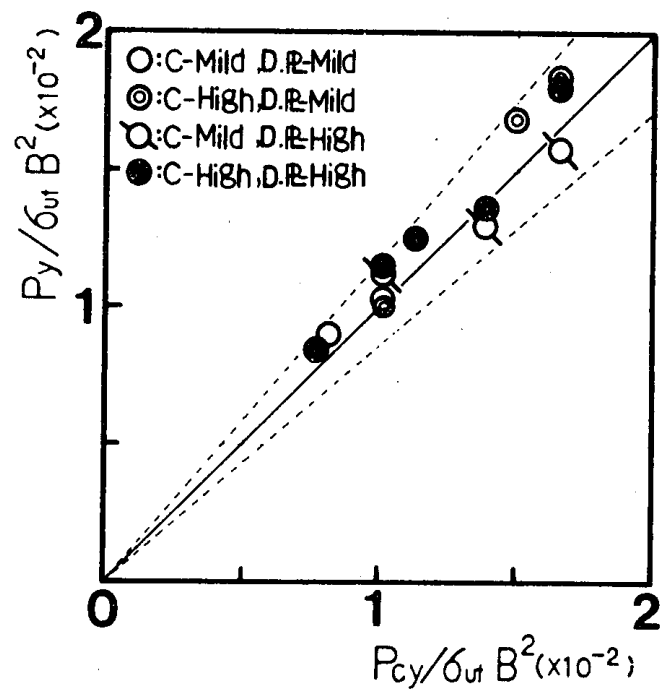

Fig. 8 Comparison between $P_{y}$ and $P_{c y}$

溶接に，強度の高い方に見合った溶接棒を使用した場合 のすみ肉溶接継手の強度試験を行い, 本供試体程度の板 厚では，継手の耐力は使用した溶接棒の溶着金属の強度 に支配されることを報告している。したがって，この種 の異種鋼材接合部の耐力評価に際して，普通鋼であるダ イアフラム材の強度を使用することは, 耐力を過少評価 することにつながる。試みに，溶着金属の引張強さに対 応している柱の引張強さ $\sigma_{u c}$ を $(4)$. 式，（5）式の $\sigma_{u s}$ の代りに使用し，実験値と推定值の比を求めてみる。結 果をTable 7 に示す。 $\sigma_{u c}$ を用いた場合，推定式は耐力 を過大評価する傾向にあるが，ダイアフラム材の $\sigma_{u s}$ を 使用した場合よりも推定精度が良いことが分かる。

3-4 4 枚板溶接による角形鋼管の場合 ${ }^{5)}$

提案した局部耐力の推定式は冷間ロール成形あるいは 冷間プレス成形により製造されたコーナー部にアールを もつ角形鋼管についての実験結果を基に誘導されてい る。

前報で，製造方法の異なる 3 種頪の角形鋼管を用いた 接合部が局部破壊する場合，4枚板溶接によるもの（以 下ビルトアップ鋼管）は，コーナー部にアールをもつも のに比べ，最大耐力は低下する傾向にあることを指摘し

Table 6

\begin{tabular}{c|c|c|c|c|c}
\hline & $P_{y}$ & $P-\delta_{L}$ & $P_{\max }$ & $\sigma_{y f}$ & $\sigma_{u f}$ \\
\hline$\frac{T S-6 H}{\mathrm{TS}-6 \mathrm{HB}}$ & 1.27 & 1.20 & 0.95 & 2.42 & 1.56 \\
\hline$\frac{\mathrm{T} 25 \mathrm{~S}-6 \mathrm{HBH}}{\mathrm{T} 25 \mathrm{~S}-6 \mathrm{HB}}$ & 1.30 & 1.20 & - & 1.17 & 1.12 \\
\hline$\frac{\mathrm{T} 25 \mathrm{~S}-9 \mathrm{HAH}}{\mathrm{T} 25 \mathrm{~S}-9 \mathrm{HA}}$ & 1.19 & 1.10 & 1.04 & 1.22 & 1.20 \\
\hline
\end{tabular}

Table 7 Comparison between Test and Predicted Results

\begin{tabular}{l|c|c|c|c}
\hline \multirow{2}{*}{ specimen } & \multicolumn{2}{|c|}{ by $\sigma_{\mathrm{uf}}$} & \multicolumn{2}{c}{ by $\sigma_{\mathrm{uc}}$} \\
\cline { 2 - 5 } & Py/Pcy & Pmax/Pcmax & Py/Pcy & Pmax/Pcmax \\
\hline TS -6 $\mathrm{H}$ B & 1.13 & 1.37 & 0.83 & 1.01 \\
T25S-6HB & 0.99 & $>0.85$ & 0.90 & $>0.77$ \\
T25S-9HA & 1.11 & 1.15 & 0.94 & 0.97 \\
\hline
\end{tabular}


た。本節では既報5)のビルトアップ鋼管を用いた実験結 果について，提案した耐力推定式の適用性を検討する。

供試体は，鋼管径の $10 \%$ 幅のダイアフラムをもつも の 1 種類であるが，使用鋼種は 4 種類，加力形式は引張 (TS) および圧縮 (CS) の両形式で，合形 8 体である。 供試体の溶接には，鋼種に対応する溶接棒が使用されて いる。供武体の寸法および使用材の機械的性質を Table 8 に示す。

引張形式の供試体はすべて加力用つかみ部のきれつで 最大耐力に達したため，接合部の最大耐力は不明である。 王縮形式の供試体はすべてダイアフラム部の座屈で最大 耐力に達したが，明瞭な局部変形が認められ，得られた 最大耐力はほぼ局部破壊耐力に等しいと判断される。

Table 9 に実験値と推定値の比較を示す。いずれの供 試体においても推定式は耐力を危険側に評価する傾向に あり，TS一 41 の降伏耐力を除けば，10\% 程度の過大 評価となっている。

この実験での圧縮形式の降伏耐力は引張形式の場合と ほほ等しい。この種の接合部の耐力は圧縮形式の方が引 張形式より低くなるのが一般であるが，本節での圧縮形 式の供試体には，フランジ板の座屈を防ぐためにフラン ジ板の板幅の中央に沿って縦方向スチフナーが入ってい るため，耐力が高くなったものと考えられる。

また, 鋼種が変化しても TS-41 を除き, 実験値と推 定值の比は大略同じで，3-3-1 で述べたように，高張力 鋼の場合でも接合部の局部耐力はダイアフラム材の引張 強さ $\sigma_{u s}$ に支配されている。

3-5 三角板により補剛された接合部 ${ }^{6)}$

供試体はFig. 9 に示すように, 直交方向フランジ板 があり，三角板が両方向のはりフランジに溶接されてお り，本研究で対象とした補剛形式とは異なっている。

耐力評価に際し，この接合部を Fig. 9 中に破線で示 すように，柱コーナー部より $45^{\circ}$ に引いた線と三角板の
底辺との交点と，はりフランジまでをダイアフラムせい $\left(h_{D}=L / 2\right)$ とする一方向のみのフランジ板をもつ接合 部と考える。その結果，この接合部は，溶接継目位置の 相違を別にすれば，推定式誘導に用いた接合部が緩やか なテーパー $\left(\theta \doteqdot 10^{\circ}\right)$ を有していたのに対し, 急激なテー パー $\left(\theta=45^{\circ}\right)$ 部をもつ場合に対応しているとみなすこ とができる。

Table 10 に供試体諸元を示す。補強の三角板が大き いものについては,ダイアフラムせいと鋼管幅の比 $h_{D} / B$ が 0.2 よりも大きい $\left(h_{D}=0.25,0.375\right)$ ものも 6 体ある。

すべての供試体は加力側フランジ板と三角板の交点の フランジ板のきれつにより最大耐力に達している。

Table 11 に実験結果と推定値を示す。Fig. 10 および Fig. 11 に両者の関係を示す。図中の破線はFig. 2 およ びFig. 3 に示した $95 \%$ 信頼帯である。最大耐力および 降伏耐力とも. $25 \%$ 程度危険側の推定になっているもの

Table 10 Details of Test Specimens (Ref. 6))

\begin{tabular}{|c|c|c|c|c|}
\hline \multirow{2}{*}{ Specimen } & $\mathrm{B} \times \mathrm{B} \times \mathrm{T}$ & $t$ & $\mathrm{~L}$ & ouf \\
\hline & $\mathrm{mm}$ & $\mathrm{mm}$ & $\mathrm{mm}$ & $t / \mathrm{cm}^{2}$ \\
\hline $\begin{array}{l}R 2-5 \\
R 2-10-1 \\
R 2-10-2 \\
R 2-15 \\
R^{\prime} 2-5 \\
R^{\prime} 2-10-1 \\
S 2-0 \\
\text { S2-5 } \\
\text { S2-7.5 } \\
\text { S2-10 } \\
\text { S3-10 } \\
\text { S } 3-15 \\
\text { S4-10 } \\
\text { S5-8.5 }\end{array}$ & $\begin{array}{l}300 \times 300 \times 9 *^{2} \\
300 \times 300 \times 12 *^{2} \\
250 \times 250 \times 9 * 3\end{array}$ & $\begin{array}{r}9 \\
9 \\
12 \\
9 \\
9 \\
9 \\
6 \\
6 \\
6 \\
6 \\
9 \\
9 \\
12 \\
9\end{array}$ & $\begin{array}{r}50 \\
100 \\
100 \\
150 \\
50 \\
100 \\
0 \\
50 \\
75 \\
100 \\
100 \\
150 \\
100 \\
85\end{array}$ & $\begin{array}{l}4.41 \\
4.41 \\
4.65 \\
4.61 \\
4.36 \\
4.36 \\
4.57 \\
4.57 \\
4.57 \\
4.57 \\
4.50 \\
4.50 \\
4.66 \\
4.69\end{array}$ \\
\hline $\begin{array}{l}* 1: \text { RHS } \\
*^{2}: \text { RHS } \\
\\
\text { for }\end{array}$ & $\begin{array}{l}\text { formed by c } \\
\text { fabricated } \\
\text { ed by cold }\end{array}$ & & 1 & $s$ \\
\hline
\end{tabular}

Table 8 Detail of Test Specimens and Mechanical Properties (Ref. 5)

\begin{tabular}{|c|c|c|c|c|c|c|c|c|}
\hline \multirow{2}{*}{ Specimen } & $\mathrm{B} \times \mathrm{B} \times \mathrm{T}$ & & $h_{D}$ & \multirow{2}{*}{ Grade } & \multirow{2}{*}{\multicolumn{2}{|c|}{$\sigma_{y c} \sigma_{\mathrm{t} / \mathrm{cm}^{2}}^{\sigma_{\mathrm{c}}}$}} & \multirow{2}{*}{\multicolumn{2}{|c|}{$\sigma_{\mathrm{yf}}^{\sigma_{\mathrm{uf}}} \mathrm{cm}^{2}$}} \\
\hline & $\mathrm{mm}$ & & & & & & & \\
\hline $\begin{array}{c}\mathrm{TS}-41, \mathrm{CS}-41 \\
\mathrm{TS}-50, \mathrm{CS}-50 \\
\mathrm{TS}-50 \mathrm{Y}, \mathrm{CS}-50 \mathrm{Y} \\
\mathrm{TS}-58, \mathrm{CS}-58\end{array}$ & $350 \times 350 \times 16$ & 13 & 35 & & $\begin{array}{l}2.76 \\
3.60 \\
4.71 \\
5.93\end{array}$ & $\begin{array}{l}4.67 \\
5.50 \\
6.05 \\
6.74\end{array}$ & $\begin{array}{l}2.94 \\
4.45 \\
4.02 \\
5.15\end{array}$ & $\begin{array}{l}4.71 \\
5.55 \\
5.59 \\
5.87\end{array}$ \\
\hline
\end{tabular}

Table 9 Comparison between Test and Predicted Results

\begin{tabular}{|c|c|c|c|c|c|c|}
\hline \multirow[b]{2}{*}{ Specimen } & $P_{y}$ & $P_{\max }$ & $P_{c y}$ & $\mathrm{P}_{\text {cmax }}$ & \multirow{2}{*}{$\frac{P_{y}}{P_{c y}}$} & $P_{\max }$ \\
\hline & \multicolumn{2}{|c|}{$\operatorname{ton} f$} & \multicolumn{2}{|c|}{$\operatorname{ton} f$} & & $\overline{P_{\operatorname{cmax}}}$ \\
\hline $\mathrm{TS}-41$ & 70 & - & 96.5 & - & 0.73 & - \\
\hline TS -50 & 100 & - & 113.7 & - & 0.88 & - \\
\hline$T S-50 Y$ & 110 & - & 114.6 & - & 0.96 & - \\
\hline $\mathrm{TS}-58$ & 110 & - & 120.3 & - & 0.91 & - \\
\hline $\mathrm{CS}-41$ & 90 & 152 & 96.5 & 166.4 & 0.93 & 0.91 \\
\hline $\mathrm{CS}-50$ & 100 & 177 & 113.7 & 196.0 & 0.88 & 0.90 \\
\hline CS-50Y & 110 & 187 & 114.6 & 197.5 & 0.96 & 0.95 \\
\hline $\mathrm{CS}-58$ & 120 & 186 & 120.3 & 207.3 & 1.00 & 0.90 \\
\hline
\end{tabular}

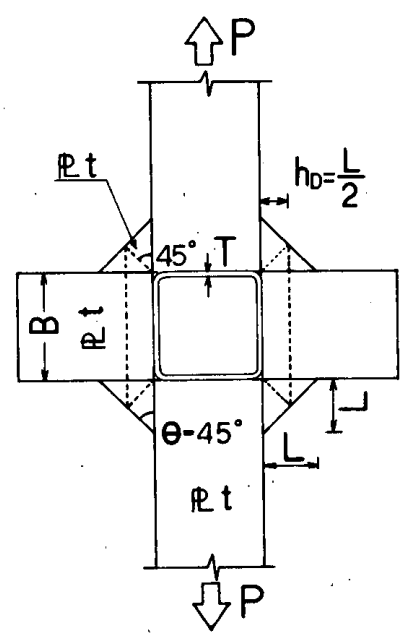

Fig. 9 Test specimen stiffened by triangular plates (Ref 6)) 
ものもみられるが，三角板の大きいものも含めて大半の ものは $95 \%$ 信頼帯内に入っており, 提案した耐力推定 式で三角板補剛された接合部の耐力評価は可能である。

3-6 片側載荷の接合部 ${ }^{7), 81}$

供試体形状および載荷形式を Fig. 12 に示す。ダイア フラムの形式は推定式誘導の基になった供試体と同じで

Table 11 Comparison between Test and Predicted Results

\begin{tabular}{|c|c|c|c|c|c|c|}
\hline \multirow{2}{*}{ Specimen } & $\mathrm{P}_{\mathrm{y}}$ & $P_{\max }$ & $P_{c y}$ & $P_{\text {cmax }}$ & \multirow{2}{*}{$\frac{P_{y}}{P_{c y}}$} & \multirow{2}{*}{$\frac{\mathrm{P}_{\max }}{\mathrm{P}_{\text {cmax }}}$} \\
\hline & \multicolumn{2}{|c|}{$\frac{y}{\operatorname{ton} f}$} & \multicolumn{2}{|c|}{$\operatorname{tonf}$} & & \\
\hline$R 2-5$ & 23.5 & 43.3 & 25.9 & 44.6 & 0.91 & 0.97 \\
\hline R2-10-1 & 35.5 & 61.1 & 31.5 & 54.3 & 1.13 & 1.13 \\
\hline$R 2-10-2$ & 37.5 & 62.9 & 40.2 & 69.3 & 0.93 & 0.91 \\
\hline $\mathrm{R} 2-15$ & 35.0 & 69.8 & 37.2 & 64.2 & 0.94 & 1.09 \\
\hline$R^{\prime} 2-5$ & 23.0 & 39.8 & 25.6 & 44.1 & 0.90 & 0.90 \\
\hline$R^{\prime} 2-10-1$ & 31.5 & 53.8 & 31.1 & 53.7 & 1.01 & 1.00 \\
\hline$S 2-0$ & 9.5 & 21.8 & 11.8 & 20.4 & 0.80 & 1.07 \\
\hline$S 2-5$ & 15.4 & 27.0 & 20.4 & 35.2 & 0.75 & 0.77 \\
\hline$s 2-7.5$ & 22.5 & 33.9 & 22.9 & 39.5 & 0.98 & 0.86 \\
\hline$S 2-10$ & 22.0 & 39.0 & 24.9 & 42.9 & 0.88 & 0.91 \\
\hline s3-10 & 40.0 & 74.6 & 49.0 & 84.5 & 0.82 & 0.88 \\
\hline s3-15 & 54.6 & 84.0 & 55.2 & 95.1 & 0.99 & 0.88 \\
\hline$S 4-10$ & 56.1 & 104.4 & 75.7 & 130.6 & 0.74 & 0.80 \\
\hline S5-8.5 & 39.2 & 62.8 & 46.0 & 79.2 & 0.85 & 0.79 \\
\hline
\end{tabular}

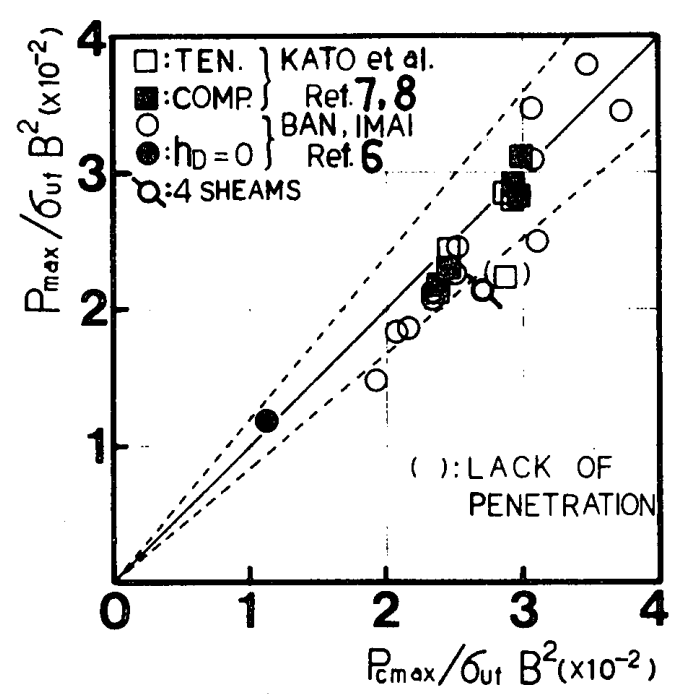

Fig. 10 Comparison between $P_{\max }$ and $P_{c \max }$

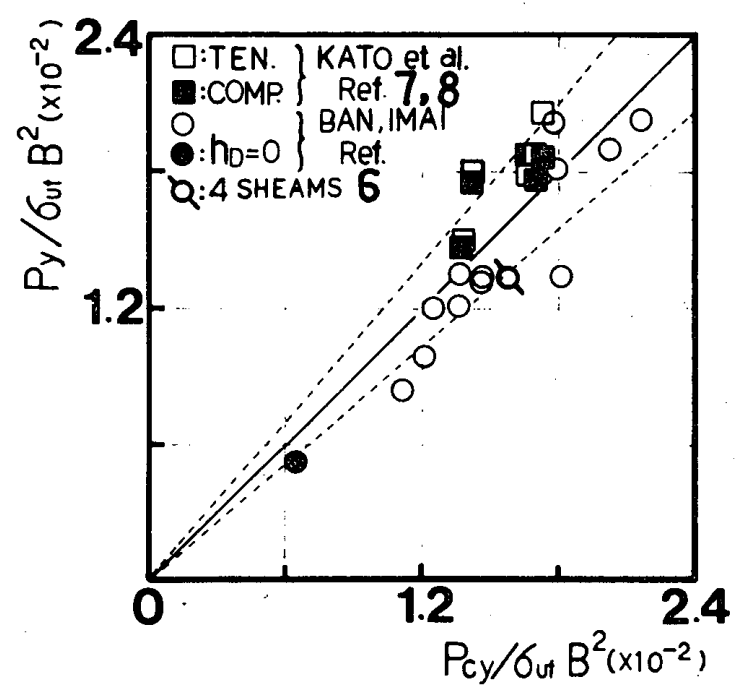

Fig. 11 Comparison between $P_{y}$ and $P_{c y}$
あり，各部材寸法比は䩂力推定式の適用範囲を満たして いる。柱とダイアフラムの溶接は裹当金を用いたレ形開 先の突き合せ溶接である。

載荷は，柱を単純支持しておきフランジ板を通して片 側の引張 $(T-$ Type ) あるいは圧縮 $(C-$ Type $)$ 荷重 を加える形式である。

供試体の諸元を Table 12, 実験結果と推定值を Table 13 に示す。引張タイプの供試体はすべて柱コ一 ナ一部の溶接部のきれつで, 圧縮夕イプはダイアフラム 部の局部座屈で最大耐力に達した。最大耐力時の鋼管の 局部変形量は引張夕イプ, 圧縮夕イプとも鋼管厚程度で あり，フランジ板の局部座屈で耐力が決定した圧縮タイ プでも鋼管自体もほぼ局部耐力に達していたと判断され る”。

Fig. 10 およびFig. 11 に実験値と推定値の関係を示 す。降伏耐力については，推定式は耐力を過少評価する
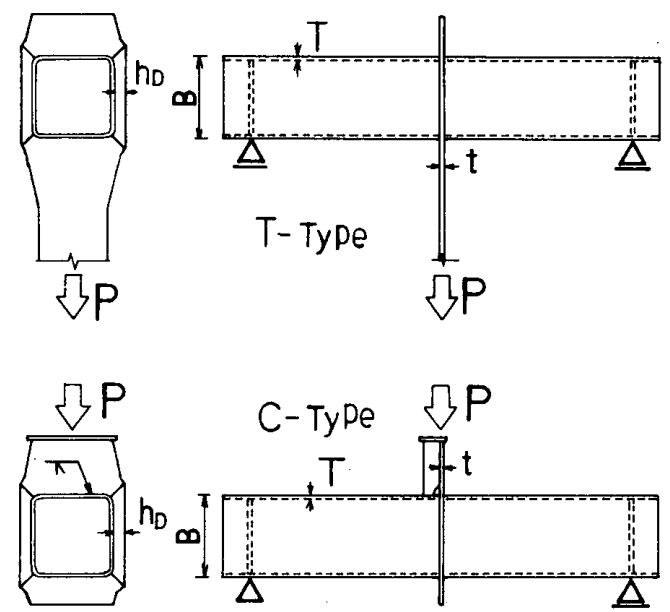

Fig. 12 Specimens subjected to load on one side only (Refs. 7), 8))

Table 12 Details of Test Specimens (Refs, 7), 8))

\begin{tabular}{l|c|rc|l}
\hline & $B \times B \times \mathrm{T}$ & $\mathrm{t}$ & $\mathrm{h}_{\mathrm{D}}$ & \multicolumn{1}{|c}{$\sigma_{\mathrm{uf}}$} \\
\cline { 2 - 5 } & $\mathrm{mm}$ & $\mathrm{mm}$ & $\mathrm{mm}$ & \multicolumn{1}{|c}{$\mathrm{t} / \mathrm{cm}^{2}$} \\
\hline T1 ,C1 & $250 \times 250 \times 9$ & 9 & 30 & 4.43 \\
T2-2,C2-2 & & 12 & 30 & $5.03,4.41$ \\
T3, C3 & $300 \times 300 \times 9$ & 12 & 40 & 4.41 \\
T4, C4 & 16 & 40 & 4.35 \\
T5,C5 & $300 \times 300 \times 12$ & 12 & 40 & 4.45 \\
\hline
\end{tabular}

Table 13 Comparison between Test and Predicted Pesults

\begin{tabular}{|c|c|c|c|c|c|c|c|}
\hline & $\mathrm{Py}_{\mathrm{y}}$ & $\mathrm{P}_{\max }$ & $P_{c y}$ & $P_{\text {cmax }}$ & \multirow{2}{*}{$\frac{P_{y}}{P_{c y}}$} & \multirow{2}{*}{\begin{tabular}{|c|}
$\mathrm{P}_{\max }$ \\
$\mathrm{P}_{\text {cmax }}$
\end{tabular}} & \multirow{2}{*}{$\begin{array}{l}\text { Failure } \\
\text { mode }\end{array}$} \\
\hline & \multicolumn{2}{|c|}{$\operatorname{ton} \mathrm{f}$} & \multicolumn{2}{|c|}{ tonf } & & & \\
\hline $\mathrm{T} 1$ & 50.0 & 67.6 & 39.6 & 68.2 & 1.26 & 0.99 & $\mathrm{Cr}$ \\
\hline T2-2 & 65.0 & 88.9 & 54.4 & 93.8 & 1.19 & 0.95 & $\mathrm{Cr}$ \\
\hline T3 & 60.0 & 84.8 & 54.7 & 94.3 & 1.10 & 0.90 & $\mathrm{Cr}$ \\
\hline $\mathrm{T} 4$ & 70.0 & 87.8 & 65.4 & 112.7 & 1.07 & 0.78 & Cr* \\
\hline T5 & 75.0 & 116.0 & 68.2 & 117.6 & 1.10 & 0.99 & $\mathrm{Cr}$ \\
\hline Cl & 48.6 & 63.6 & 39.6 & 68.2 & 1.23 & 0.93 & $\overline{\mathrm{Lb}}$ \\
\hline C2-2 & 51.4 & 86.1 & 47.7 & 82.3 & 1.08 & 1.05 & Lb \\
\hline C3 & 58.5 & 85.8 & 54.7 & 94.3 & 1.07 & 0.91 & $\mathrm{Lb}$ \\
\hline C4 & 73.5 & 112.7 & 65.4 & 112.7 & 1.12 & 1.00 & $\mathrm{Lb}$ \\
\hline $\mathrm{C5}$ & 71.0 & 111.8 & 68.2 & 117.6 & 1.04 & 0.95 & $\mathrm{Lb}$ \\
\hline$\hat{c}$ & & & 110 & & & & \\
\hline Lb : & & T & & & & & \\
\hline
\end{tabular}


傾向にあるが，一部の供武体を除き，引張タイプ，王縮 タイプとも $95 \%$ 信頼帯の幅の中に入っており，十分な 精度で耐力を推定している。最大耐力については，溶接 部の溶け込み不足のため早期に破壊が生じた $\mathrm{T}-4$ 以外 はすべて $95 \%$ 信頼帯内に入っており，かつ推定精度は 極めて高い。王縮タイプの供試体は，3-4 節の場合と同 様に, フランジ板の早期の座屈を防ぐため縦スチフナー が溶接されている。その結果, 引張タイプと王縮タイプ の間には大きな耐力差はない。

提案式が片側載荷の場合の局部降伏，破壊耐力を適切 に評価できることは，これらの式が水平荷重時における 接合部の局部降伏および破壊耐力の推定にも有効である ことを示唆している。水平荷重時状態における耐力推定 式の適用については今後検討する予定である。

3-7 実際の柱・はり接合部の場合 ${ }^{9), 10)}$

前節までに検討した供試体はすべて接合部の引張側あ るいは圧縮側のみをとり出した模型供試体であり，曲げ モーメントとせん断力を受け；引張側と圧縮側が同時に 存在し，鋼管の局部変形に関しては互いに干渉し合う奏 際の柱・はり接合部とは性状が異なっている。本節では 実際の柱・はり接合部により近い形状の供試体について 耐力推定式の有効性を検討する。

供試体はFig. 13 に示すように角形鋼管柱に H 形鋼は りを溶接接合した十字形供試体である。Table 14 に寸 法諸元を示す。供試体は柱がロール成形鋼管あるいはプ レス成形鎙管によるもの ${ }^{9)}$ とビルトアップ鋼管の場合 ${ }^{10)}$

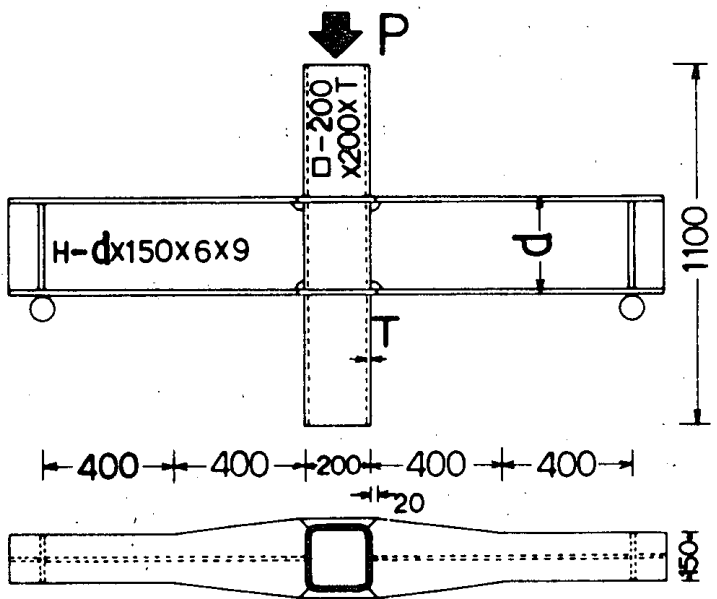

Fig. 13 Specimen for actual connection

の 2 種類に分かれる。

載荷方法は，接合部の局部変形挙動に着目するため, はり両端をローラー支持し柱頭に荷重を加える対称荷重 形式とした。使用鋼種はSTKR 41 および SS 41 である。

1) ロール成形鋼管およびプレス成形鋼管の場合 ${ }^{9)}$ : ダイアフラムせいはすべて $h_{D}=0.1 B$ で, 補剛方法の詳 細は耐力式誘導の基本資料になった単純模型供試体 $T S-9 B, T S-6 B, T S-4.5 B$ と同じである。はりせ いは鋼管幅の 1.5 倍 $(d=300 \mathrm{~mm})$ を標準としたが, BS-6 B シリーズについては，接合部の引張側と圧縮 側の相互干渉による影響を調べるため，はりせいと鋼管 幅の比 $d / B$ が 1.0 および 2.0 のもについても実験を

Table 14 Datails of Test Specimens (Refs. 9), 10))

\begin{tabular}{|c|c|c|c|c|c|}
\hline \multirow[t]{2}{*}{ Specimen } & $\begin{array}{l}\text { Column } \\
\mathrm{B} \times \mathrm{B} \times \mathrm{T}\end{array}$ & $\begin{array}{l}\text { Beam } \\
\mathrm{d} \times \mathrm{b} \times \mathrm{t}_{\mathrm{w}} \times \mathrm{t}\end{array}$ & \multirow[t]{2}{*}{$\begin{array}{c}\text { Dia- } \\
\text { phragm } \\
\text { t } \times \text { hD }\end{array}$} & \multirow{2}{*}{$\begin{array}{c}\sigma u f \\
t / \mathrm{cm}^{2} \\
\end{array}$} & \multirow{2}{*}{ Ref. } \\
\hline & & $\mathrm{mm}$ & & & \\
\hline $\begin{array}{l}B S-9 B \\
B S-6 B \\
B S-6 B-200 \\
B S-6 B-400 \\
B S-4.5 B \\
\end{array}$ & $\begin{array}{l}200 \times 200 \times 9 \\
200 \times 200 \times 6 \\
200 \times 200 \times 4.5\end{array}$ & $\begin{array}{l}300 \times 150 \times 6 \times 9 \\
300 \times 150 \times 6 \times 9 \\
200 \times 150 \times 6 \times 9 \\
400 \times 150 \times 6 \times 9 \\
300 \times 150 \times 6 \times 9 \\
\end{array}$ & $9 \times 20$ & $\begin{array}{l}4.59 \\
4.59 \\
4.80 \\
4.80 \\
4.59 \\
\end{array}$ & (9) \\
\hline $\begin{array}{l}B-1 \\
B-2 \\
B-3\end{array}$ & $350 \times 350 \times 16$ & $400 \times 200 \times 8 \times 13$ & $\begin{array}{l}13 \times 0 \\
13 \times 35 \\
13 \times 70\end{array}$ & 4.90 & $(10)$ \\
\hline
\end{tabular}

Table 15 Comparison between Test and Predicted Results

\begin{tabular}{|c|c|c|c|c|c|c|c|c|c|}
\hline \multirow[t]{2}{*}{ t? } & My & $M_{\max }$ & $P_{\text {Ly }}$ & $P_{L \max }$ & $P_{\text {cy }}$ & $P_{\text {cmax }}$ & $\mathrm{PLy}_{\mathrm{L}}$ & Plmax & \multirow{2}{*}{$\begin{array}{l}\text { Failure } \\
\text { mode }\end{array}$} \\
\hline & \multicolumn{2}{|c|}{$t f \cdot m$} & \multicolumn{2}{|c|}{$\tan f$} & \multicolumn{2}{|c|}{ tonf } & $\widetilde{P_{c y}}$ & $\mathrm{P}_{\text {cmax }}$ & \\
\hline BS-9B & 9.6 & 17.5 & 33.0 & 60.3 & 34.5 & 59.4 & 0.96 & 1.02 & $\mathrm{Lb}, \mathrm{Cr}$ \\
\hline$B S-6 B$ & 7.2 & 13.2 & 24.7 & 45.5 & 25.4 & 43.7 & 0.97 & 1.04 & $\mathrm{Lb}$ \\
\hline$B S-6 B-200$ & 5.6 & 9.7 & 29.3 & 50.7 & 26.5 & 45.7 & 1.11 & 1.11 & L.b \\
\hline$B S-6 B-400$ & 11.2 & 18.5 & 28.6 & 47.4 & 26.5 & 45.7 & 1.08 & 1.04 & Lb \\
\hline $\mathrm{BS}-4.5 \mathrm{~B}$ & 6.4 & 11.5 & 22.0 & 39.5 & 20.5 & 35.4 & 1.07 & 1.12 & $\mathrm{Cr}$ \\
\hline$B-1$ & 20.6 & 36.7 & 53.3 & 94.9 & 68.2 & 117.6 & 0.78 & 0.81 & $\mathrm{Cr}$ \\
\hline B-2 & $30.9^{\prime}$ & 43.3 & 79.9 & 111.9 & 100.4 & 173.1 & 0.80 & 0.64 & $\mathrm{Cr} *$ \\
\hline$B-3$ & 33.0 & 46.6 & 85.3 & 120.4 & 119.5 & 206.0 & 0.71 & 0.59 & Sw \\
\hline
\end{tabular}

Lb : Local buckling of diaphragm

Cr : Crack in weld

Sw : Shear failure of beam web

* : Poor welding 
行った。

実験結果を Table 15 に示す。破壊形式はダイアフラ ム部の局部座屈あるいは溶接部のきれつであるが，いず れの場合も鋼管の局部変形に起因しており，やや早期に きれつが生じた BS一9 B 以外，最大荷重時には鋼管厚 以上の局部変形がみられた。

Fig. 14 およびFig. 15 に実験值と推定値の関係を示 す。ここで, 局部耐力の実験值は柱接合面でのはり端モ一 メントをはりフランジ重心間距離で除した值 $\left(P_{L}=M /(\right.$ $d-t)$ ) である。同図には比較のため単純引張模型供試 体の結果も示している。最大耐力および降伏耐力ともす べての供武体の実験結果は（4）式，（5）式の $95 \%$ 信頼帯の幅の中に入っており，推定式は実際の柱・はり 接合部の局部破壊耐力の推定に関しても有効であること が分かる。また $d / B=1.0$ の場合, 実験値之推定值の 比は, $d / B=1.5$ および 2.0 のものより高く, 引張側と 王縮側の局部変形の相互干渉の影響が認められる。しか し $d / B$ が 1.5 以上ではその効果はほぼ等しい。

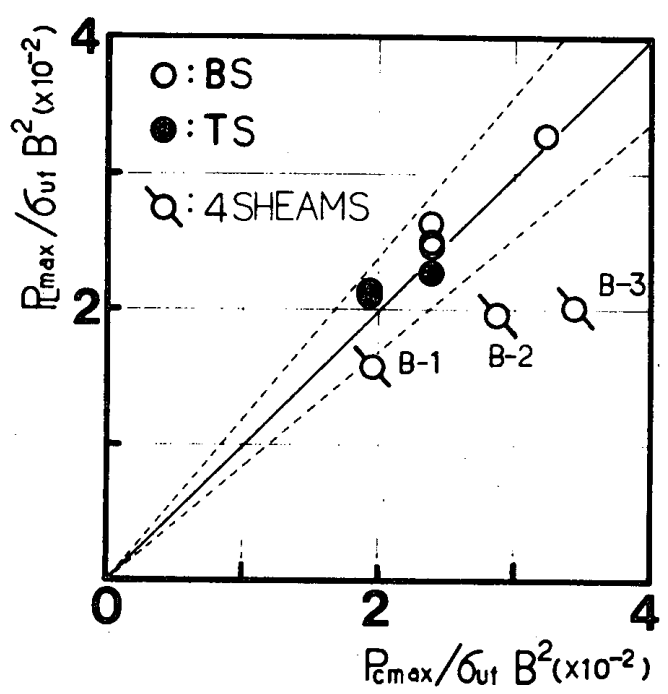

Fig. 14 Comparison between Pmax and Pcmax

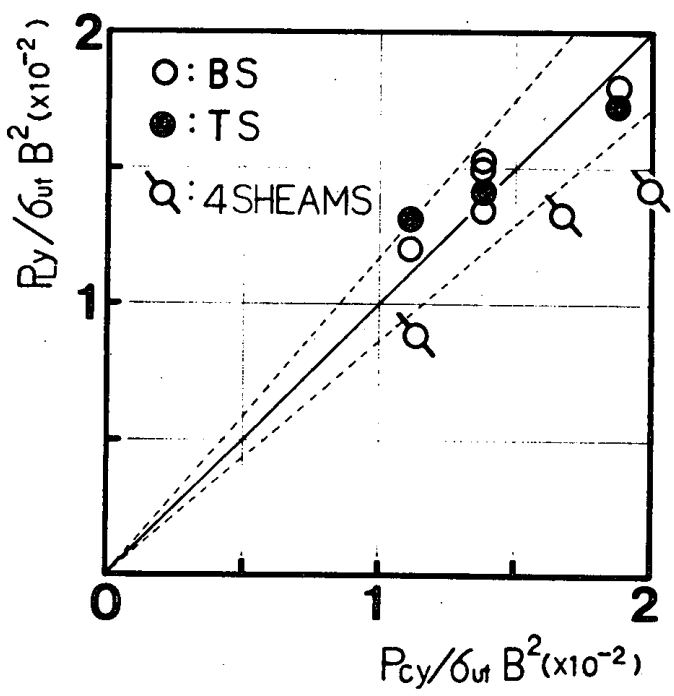

Fig. 15 Comparison between $P_{y}$ and $P_{c y}$
接合部の引張側を対象とした供試体の実験結果に基づ き誘導された推定式であるにもかかわらず，接合部の圧 縮側で破壊した場合でも提案式で耐力推定が可能である のは，）この種の接合部の耐力は, 圧縮側の方が引張 側より低いのが一般であるが，はりせいが鋼管幅の1 2 倍の範囲では鋼管の引張側と圧縮側の局部変形が相互 に影響し合い，また，はりウェブの拘束効果もあり圧縮 側の耐力がそれほど低下しないこと, ii ) 推定式を誘導 する際の基本資料となった供試体は，柱とダイアフラム がすみ肉溶接されているものが大半であり，この部分が 突き合せ溶接されたものに比べて耐力が劣り ${ }^{1)}$, 結果と して圧縮側の局部破壊耐力と等しくなる，等の理由によ るものと考えられる。

2）ビルトアップ鍓管の場合 ${ }^{10)}$

供試体はダイアフラムせいを変化させた 3 体である。 実験結果を Table 15 に示す。B-1 および B-2 は引 張側の溶接部のきれつにより最大耐力に達したが，B一 2 のダイアフラムの溶接部にはスラグの巻き込みがみら れ，局部変形も小さく，この供試体は溶接欠陥により早 期に破壊したと考えられる。一方，補剛が十分であった $\mathrm{B}$-3 は，はりウェブのせん断破壊により最大耐力に達 した。

実験値と推定値の関係を Fig. 14 および Fig. 15 に示 す。早期にきれつが生じた B-2 の最大耐力とはりウェ ブがせん断降伏，せん断破壊した B-3 の降伏および最 大耐力は推定值よりかなり低くなっている。一方，鋼管 の局部変形に起因して耐力の決まった $\mathrm{B}-1$ の降伏およ び最大耐力, B-2 の降伏耐力は推定値より $20 \%$ 程度 低いが推定值と良い相関をもっている。3-4 節の単純引 張模型供試体の場合も耐力式は実験値を $10 \%$ 程度過大 評価する傾向にあったことより，ビルトアップ鋼管柱接 合部が局部破壊する場合は，コーナー部にアールをもつ 角形鋼管の場合に比べて局部耐力は低下し，提案した耐 力推定式では耐力を $20 \%$ 程度過大評価すると考えられ る。

\section{4. 結 論}

外ダイアフラムにより補剛された角形鋼管柱接合部の 局部破壊に対する耐力を知るため，接合部を模型化した 供試体の引張実験結果に基づき，推計学的な立場から考 察した。その結果，以下のことが明らかになった。

1）ロール成形鋼管あるいはプレス成形鋼管を用いた 接合部の寸法諸元を変化させた 18 体の実験結果に基づ き，次元解析と回帰分析により次の耐力式を得た。

最大耐力について：

$$
\frac{P_{c \max }}{\sigma_{u s} \cdot B^{2}}=3.85\left(\frac{T}{B}\right)^{2 / 3}\left(\frac{t}{h_{D}+T}\right)^{2 / 3}\left(\frac{h_{D}+T}{B}\right) \cdots(4)
$$

降伏耐力について：

$$
P_{c y}=0.58 P_{c \max }
$$


上式誘導の基になった供試体の寸法範囲は $B / T=22$ $\sim 67, h_{D} / B=0.1 \sim 0.2, \cdot t / T=0.75 \sim 2.0$ で, かつ使用 材の鋼種はSTKR 41 および SS 41 でダイアフラム材の 引張強さは $\sigma_{u s}=3.34 \sim 5.40 \mathrm{t} / \mathrm{cm}^{2}$ である。

2）フランジ板が破断した場合でも接合部の局部降伏 に対しては提案式は有効である。

3） $h_{D}=0$ の接合部に対しても（4）式および（5） 式で耐力評価ができる。

4）柱，ダイアフラムとも高張力鋼の場合でも提案式 は実験結果を精度良く評価しうる。

5）柱が普通鋼でダイアフラムが高張力鋼の場合は (4)式および( 5 )式で実験結果を精度良く推定できる。 6）一方，柱のみに高張力鋼を使用した接合部では， 耐力推定式は実験值を過少評価する。この原因は, 高張 力鋼用の溶接棒を使用した溶接部のきれつで最大耐力に 達したにもかかわらず，普通鋼であるダイアフラムの $\sigma_{u f}$ を使用したことにある。

7）ビルトアップ鋼管柱接合部の局部耐力は, 本推定 式により $20 \%$ 程度過大評価される。

8）三角板により補強され，フランジ板の形状が急変 する場合でも，三角板の辺長の $1 / 2$ をダイアフラムせい と考えることにより，耐力を精度良く評価することがで きる。

9）フランジ板より片側荷重をうける接合部でも，提 案式は耐力を精度良く評価しうる。

10）提案した耐力推定式は，実際の柱・はり接合部の 状態に近い十字形供試体の局部破壊および降伏耐力を精 度良く評価しており，外ダイアフラム形式の接合部の局 部耐力推定に極めて有効である。

11）提案した耐力式は実用的な溶接方法により製作さ れた供試体の実験結果に基づいているため, 実施工の構 造物に対しても，適切な溶接施工がなされていれば，安 全側の評価を与えると考えられる。

注

接合部耐力に影響を与える使用材の機械的性質としては鋼管 およびダイアフラムの降伏点, 引張強度, 降伏比等が考えられる。 ここでは，簡便な設計式を得ることを目的とし，これらの諸因 子のうち, 接合部耐力に最も強く影響するものを使用材の機械 的性質の指標之して用いることにした。その結果; ダイアフラ ム (フランジ板) の引張強さ $\sigma_{u s}$ が最も支配的であることが分 かった。

鋼管接合部あるいは継手の耐力式には鋼管の降伏点を使用す
るのが一般（例えば文献 3 ），11））であるが, 本研究において, 酎力推定式誘導の基本資料となった 18 体について，ダイアフラ ムの引張強さの代りに，鋼管の降伏点を使用し，（2）式を誘導 したのと同じ方法で局部破壊耐力推定式を誘導した場合, 実験 値と推定值の比の変動係数は $\mathrm{COV}=0.154$ で $95 \%$ 信頼帯は $P_{\max } / P_{c \max }=0.74 \sim 1.36$ となり（2）式に比べ極端に精度が悪 くなる。

\section{参考文献}

1）田㴊基嗣，金谷 弘，上場輝康：「角形銅管柱・H形はり 接合部の局部破壊 一角形鋼管柱溶接接合部の実験的研 究 1 一」日本建築学会構造系論文報告集, No. 349 , 昭和 60 年 3 月, pp. $71 / 80$

2) N.R. Draper and H. Smith: "Applied Regression Analysis", John Willey and Sons (1966)

3）牧野雄二, 黒羽啓明, 三井宜之：「鋼管継手の局部変形耐 力の推定一支管が玨縮力を受ける場合一」日本建築学会 論文報告集，第 251 号，昭和 52 年 1 月, pp. $45 / 55$

4）伴潔, 藤原勝義：「異種鋼材溶接組立断面の基礎実験」 日本建築学会大会学術講演梗概集, 昭和 43 年 10 月, pp. $907 / 908$

5）金谷 弘, 浦田 勲, 小川忠彦：「箱形断面柱と $\mathrm{H}$ 形は りの接合部に関する研究 (その 3 高張力鋼を使用した 場合)」日本建築学会大会学術講演梗概集, 昭和 45 年 9 月, pp. 895/896

6）伴 潔，今井克彦：「三角板により補強された角形鋼管 柱・H 形銅梁接合部の実験的研究（接合部を単純化した モデルによる実験)」日本建築学会論文報告集, 第 262 号, 昭和 52 年 12 月, pp. 73/82

7) B. Kato, Y. Maeda, and K. Sakae: "Behavior of Rigid Frame Sub-Assemblages Subjected to Horizontal Force" Proceedings of the International Conference held at Teesside Polytechnic, Joints in Structual Steelwork (1981), pp. 1.37/1.53

8）加藤 勉, 秋山 宏, 西山 功:「箱形断面柱 $\cdot \mathrm{H}$ 形はり 接合部の実験的研究一外ダイアフラムの強度の検討のた めの基礎的実験一」日本建築学会関東支部研究報告集, 昭和 52 年, pp. $181 / 184$

9）金谷 弘，田㴊基嗣，上場輝康：「箱形断面柱亡 $\mathrm{H}$ 形は り接合部に関する研究—はりせいの異なる接合部の鉛直 荷重実験一」日本建築学会大会学術講演梗概集, 昭和 54 年 9 月, pp. $1145 / 1146$

10）伴 潔，金谷 弘, 浦田 勲：「箱形断面柱と $\mathrm{H}$ 形は りの接合部に関する研究（その1' 鉛直荷重時の実験)」 日本建築学会大会学術講演梗概集 昭和 43 年 10 月, pp. 1019/1020

11）上場輝康, 金谷 弘, 藤原勝義, 田㴊基嗣：「鋼管柱 $\cdot H$ 形はり接合部の耐力推定式一銅管柱溶接接合部の研究 II 一」 日本建築学会論文報告集, 第 325 号, 昭和 58 年 3 月, pp. $67 / 73$ 


\section{SYNOPSIS}

UDC : 624. 078. $014.27: 624.075 .2 .014 .27: 624.072 .2 .014 .5$

EMPIRICAL FORMULAE FOR LOCAL STRENGTH OF

WELDED RHS-COLUMN TO H-BEAM CONNECTIONS

-An experimental study on the welded RHS-column to beam connections Part 2-

by MOTOTSUgu TABUCHI, Res. Assoc. of Kobe Univ., M.S. Eng., HIROSHI KANATANI, Prof. of Kobe Univ., D. Eng., and TERUYASU KAMBA, Res. Assoc. of Kobe Univ., M.S. Eng., Members of A. I. I.

The paper examines the local failure of welded RHS-column to H-beam connections with exterior diaphragm in rigid steel frames.

Based on a number of simplified model test results reported in the previous paper (Ref. 1), the empirical formulae predicting the local strength of connections are derived by the dimensional analysis and the regression analysis.

The empirical formulae obtained here are as follows:

For the maximum load,

$$
\frac{P_{\mathrm{cmax}}}{\sigma_{u s} \cdot B^{2}}=3.85\left(\frac{T}{B}\right)^{2 / 3}\left(\frac{t}{h_{D}+T}\right)^{2 / 3}\left(\frac{h_{D}+T}{B}\right)
$$

For the yield load,

$$
P_{c y}=0.58 P_{\text {cmax }}
$$

The limits of application are:

$$
B / T=22 \sim 67, h_{D} / B \leqq 0.2, \quad t / T=0.75 \sim 2.0
$$

The proposed formulae are applicable to the following connections.

1) Connections fabricated by high strength steel grade SM 50 A or SM $58 Q$.

2) Connections stiffened by triangular plates (Fig. 9).

3) Connections subjected to tension or compression load on one side only (Fig. 12).

The strength of actual RHS-column to H-beam connections are predicted by the proposed formulae with sufficient accuracy by substituting $\mathrm{Pc}$ for $M /(d-t)$.

For RHS fabricated by four steel plates, the proposed formulae overestimate the strength of the connections by 20 $\%$. 